\title{
TL1A/TNFR2 Axis Enhances Immunoregulatory Effects of Bone Marrow Derived Mesenchymal Stem Cell by Indian Hedgehog Signaling Pathway
}

\author{
Mahmoud Al-Azab ${ }^{1,2}$, Williams Walana ${ }^{1,7}$, Jing Wei ${ }^{1}$, Weiping $\mathrm{Li}^{1}$, Yawei Tang ${ }^{1}$, \\ Xiaoqing $\mathrm{Wei}^{3}$, Marwan Almoiliqy ${ }^{4}$, Abdullah Shopit ${ }^{4}$, Elrayah Eltahir Abbas ${ }^{5}$, \\ Salah Adlat ${ }^{6}$, Mohammed $\mathrm{Awsh}^{4}$, Xia $\mathrm{Li}^{1}$, Bing Wang ${ }^{1}$ \\ ${ }^{1}$ Department of Immunology, College of Basic Medical Science, Dalian Medical University, Liaoning, China \\ ${ }^{2}$ Department of Immunology, Guangzhou Institute of Pediatrics, Guangzhou Women and Children's Medical Center, Guangzhou \\ Medical University, Guangzhou, China \\ ${ }^{3}$ Molecular Medicine Laboratory, College of Basic Medical Science, Dalian Medical University, Liaoning, China \\ ${ }^{4}$ Department of Pharmacology, College of Pharmacy, Dalian Medical University, Liaoning, China \\ ${ }^{5}$ Microbiology Laboratory, College of Basic Medical Science, Dalian Medical University, Liaoning, China \\ ${ }^{6}$ Key Laboratory of Molecular Epigenetics of MOE, School of Life Science, Northeast Normal University, Changchun, China \\ ${ }^{7}$ Department of Clinical Microbiology, School of Medicine and Health Sciences, University for Development Studies, Tamale, Ghana
}

Background and Objectives: The immunomodulatory potential of mesenchymal stem cells (MSCs) can be regulated by a variety of molecules, especially cytokines. The inflammatory cytokine, TNF-like ligand 1A (TL1A), has been reported as an inflammation stimulator in-multiple autoimmune diseases. Here, we studied the effects of TL1A/TNF-receptor 2 (TNFR2) pathway on the therapeutic potency of bone marrow-derived MSCs (BMSCs).

Methods and Results: BMSCs, fibroblast-like synoviocytes (FLSs), and H9 and jurkat human T lymphocytes were used in this study. BMSCs paracrine activities, differentiation, proliferation, and migration were investigated after stimulation with TL1A, and intervened with anti-TNFR2. Additionally, the effects of TL1A on BMSCs therapeutic potency were evaluated by treating RA-FLSs, and $\mathrm{H} 9$ and jurkat $\mathrm{T}$ cells with TL1A-stimulated BMSCs conditioned medium (CM). Indian hedgehog (IHH) involvement was determined by gene silencing and treatment by recombinant IHH (rIHH). TL1A induced BMSCs stemness-related genes, COX-2, IL-6, IDO, TGF- $\beta$ and HGF through TNFR2. Also, TL1A corrected biased differentiation and increased proliferation, and migration through TNFR2. Meanwhile, CM of TL1A-stimulated BMSCs decreased the inflammatory markers of RA-FLSs and T cells. Moreover, TL1A-stimulated BMSCs experienced IHH up-regulation coupled with NF- $\kappa$ B and STAT3 signaling up-regulation, while p53 and oxidative stress were down-regulated. Furthermore, treatment of BMSCs by rIHH increased their anti-inflammatory effects. More importantly, knockdown of IHH decreased the ability of TL1A-stimulated BMSCs to alleviating the inflammation in RA-FLSs and T cells.

Conclusions: This study reports the effects of TL1A/TNFR2 pathway on the biological behaviors and therapeutic potency of BMSCs through IHH. These findings could introduce novel procedures to increase the stemness of MSCs in cellular therapy.

Keywords: Bone marrow-derived mesenchymal stem cells, Tumor necrosis factor-like ligand 1A, TNF-receptor 2, Indian hedgehog

Received: October 2, 2019, Revised: September 11, 2020, Accepted: September 16, 2020, Published online: October 31, 2020

Correspondence to Bing Wang

Department of Immunology, College of Basic Medical Science, Dalian Medical University, Lvshun South Road, Dalian 116044, China

Tel: +86-411-86110294, E-mail: wbing79@126.com

Co-Correspondence to $\mathrm{Xia} \mathrm{Li}$

Department of Immunology, College of Basic Medical Science, Dalian Medical University, Lvshun South Road, Dalian 116044, China Tel: +86-411-86110346, E-mail: lixia0416@dlmedu.edu.cn

() This is an open-access article distributed under the terms of the Creative Commons Attribution Non-Commercial License (http://creativecommons.org/licenses/by-nc/4.0/), which permits unrestricted non-commercial use, distribution, and reproduction in any medium, provided the original work is properly cited.

Copyright (c) 2021 by the Korean Society for Stem Cell Research 


\section{Introduction}

Mesenchymal stem cells (MSCs) are multipotent progenitor cells capable of self-renewing, and also undergo osteogenic, adipogenic, and chondrogenic differentiations into different types of tissues. MSCs are non-hematopoietic cells which are present fundamentally in the bone marrow and in multiple other tissues and fluids including fat tissues, umbilical cord, and molar cells of dental pulp (1-5). It has been reported that MSCs are also found in the Wharton's jelly, amniotic fluid, lymph nodes, and in the subcutaneous tissues of the scalp (6). MSC does not express major histocompatibility complex (MHC) type II (HLA-DR). So, it cannot trigger an immune response in the recipient after allogeneic transfusion. Because of their ample availability and poor allogeneic antigenicity, MSCs have attracted a lot of attention in regenerative medicine, and in the treatment of autoimmune diseases and aging-related diseases (7). MSCs can promote the stromal environment of hematopoiesis (8). In addition, indoleamine 2,3 deoxygenase (IDO), transforming growth factor-beta (TGF- $\beta$ ), hepatocyte growth factor (HGF), and prostaglandin (PGE2) are very important effector molecules produced by MSCs which have a role in the immunoregulatory characteristics of MSCs $(9,10)$. Stimulation of MSCs with some cytokines, such as epidermal growth factor (EGF) and basic fibroblast growth factor (bFGF) may enhance their differentiation capacity. As well, MSCs ability to regulate immune response through MHC-independent pathways enables them to be an issue of study in the treatment of diseases related to adverse' immune response, such as autoimmune diseases (11).

Tumor necrosis factor (TNF)-like ligand 1A (TL1A) is one of the members of TNF superfamily which is referred to as TNF superfamily member 15 (TNFSF15) (12). The typical receptor for TL1A ligand is the death receptor 3 (DR3) which contain decoy receptor (DcR3) domain (13). However, it has been reported that TL1A can exert its proinflammatory effects on fibroblast-like synoviocytes (FLSs) through a novel receptor, TNF-receptor 2 (TNFR2) (14). Additionally, TL1A mediates inflammation in autoimmune diseases, particularly those related to mucosal tissues, such as inflammatory bowel diseases. This function of TL1A has been attributed to its potential to activate Thl, Th2, and Th17, and other lymphocytes (15). Stimulation of MSCs by cytokines is becoming a hot topic because of their vital roles in MSCs autocrine, paracrine, and endocrine signaling, which provide positive outputs toward cellular therapeutic potency enhancement. One example, IL-
$1 \beta$ pretreatment of MSCs from synovial tissue promoted their proliferation and enhanced chondrogenic differentiation ability (16). Besides, it has been reported that IL-1 $\beta$ enhanced MSCs migration through MMP1/proteinactivator receptor-1 (PAR1)/G-protein-coupled pathway (17). Indeed, stimulation of MSCs by TNF- $\alpha$ induced IL-10 and TGF- $\beta$ thereby recruiting MSCs to suppress inflammation (18). But, the effect of TL1A on bone marrow MSCs (BMSCs) is still not clear. Therefore, exploring the role of TL1A cytokine ligand in the biological activities of BMSCs using its novel receptor, TNFR2 may provide a new approach to enhancing BMSCs immunomodulatory capacity.

Hedgehog $(\mathrm{HH})$ is an important signaling pathway involved in tissues growth and morphogenesis at the level of embryonic development (19). Sonic HH (SHH), Indian $\mathrm{HH}(\mathrm{IHH})$, and desert (DHH) ligands, and patched 1/2 (PTCH1/2) and smoothened (Smo) trans-membranous receptors, as well as the target gene of Hedgehog, Gli, are all the members of $\mathrm{HH}$ signaling pathway. Recently, scientists declared a promising potential for $\mathrm{SHH}$ in the regeneration of cardiac tissues in an animal model, suggesting a role for $\mathrm{HH}$ signaling in improving symptoms of aging-related diseases (20). Another study revealed that IHH may induce the Wnt antagonist, SFRP1 (21), which may keep normal differentiation of MSCs and secure them from the aging fate. In our previous results, we discovered that $\mathrm{IHH}$ has an anti-aging effect on BMSCs and can promote the potency of BMSCs (22). Moreover, it has been reported that hedgehog signaling induces osteogenesis at the cost of adipogenesis in MSCs (23). Furthermore, IHH promoted the function of BMSCs in cartilage differentiation (24). The interaction of IHH with TL1A has been underscored in the inflammatory process through TNFR2 (25). Thus, the study of TL1A/IHH signaling in the therapeutic potency of BMSCs may introduce a new pathway to enhance cellular therapy using BMSCs.

In the current study, we aimed to investigate the roles of TL1A in BMSCs' biological behaviors through the novel receptor TNFR2. In addition, we tested the effects of TL1A stimulation on the anti-inflammatory property of BMSCs using FLSs from patients with rheumatoid arthritis (RA) and T cells. Moreover, due to its importance in the immunoregulatory potency of MSCs, we studied the interaction between TL1A and IHH using IHH small interference RNAs (siRNAs). 


\section{Materials and Methods}

\section{Cell lines and human samples}

Approval for the study was granted by the Dalian Medical University ethical committee on human and animal research. BMSCs and $\mathrm{H} 9$ human T lymphocytes (H9 T) cell lines were purchased from Dalian Chenyu Biotechnology Co., Ltd, China. Jurkat human T lymphocytes were collected as a gift from Peking University People's Hospital. Synovial tissues from RA patients were collected from the Orthopedics Department of the Second Affiliate Hospital of Dalian Medical University, Dalian, China, for the isolation of FLSs.

\section{FLSs isolation}

Minced synovial tissues from RA patients were enzymatically digested with collagenase type I from Clostridium histolyticum (Biotopped, China) at a concentration of 3 $\mathrm{mg} / \mathrm{ml}$ in DMEM (Biological Industries, USA) in a petri dish and at $37^{\circ} \mathrm{C}$ on a shaker for $2 \mathrm{~h}$. The tissues filtrate from $70 \mu \mathrm{M}$ pores of nylon mesh was centrifuged for 5 minutes at $300 \mathrm{~g}$ and the sediment was resuspended in adequate volume of Dulbecco's modified Eagle's medium (DMEM) supplemented with $20 \%$ fetal bovine serum (FBS) (Biological Industries, USA), $100 \mathrm{U} / \mathrm{ml}$ penicillin, and $100 \mu \mathrm{g} / \mathrm{ml}$ streptomycin $(\mathrm{P} / \mathrm{S})$, and cultured in humidified environment at $37^{\circ} \mathrm{C}$ and $5 \% \mathrm{CO}_{2}$. Three to five passages of RA-FLS were used for all experiments.

\section{IHH silencing}

Lipofectamine 2000 (Invitrogen, Guangzhou, China) and small interference RNAs (siRNAs) were used for IHH knockdown (22). Both siRNA and lipofectamine were separately incubated in $150 \mu 1 \mathrm{DMEM}$ at room temperature (RT) for 5 minutes, mixed thoroughly in RNase free sterile tube, and incubated again for 25 minutes at RT. The mixture was then added to BMSC of $60 \sim 90 \%$ confluence in 6-well plat in $1 \mathrm{ml}$ DMEM without FBS, and incubated at $37^{\circ} \mathrm{C}, 5 \% \mathrm{CO}_{2}$ and $95 \%$ humidity. The cells were used in experiments after 24 or $48 \mathrm{~h}$ incubation. The transfection effect tested by both reverse transcription-polymerase chain reaction (RT-PCR) and western blot (22). Validation of the transfection done with FAM negative control, GAPDH positive control, and siRNA negative control (Table 1) (Gene Pharma, Shanghai, China).

\section{Cell culture and treatments}

Adequate-confluence of BMSCs were propagated in DMEM with $10 \% \mathrm{FBS}, 100 \mathrm{U} / \mathrm{ml} / 100 \mu \mathrm{g} / \mathrm{ml} \mathrm{P} / \mathrm{S}$ at $37^{\circ} \mathrm{C}$, and $5 \% \mathrm{CO}_{2}$ in a humidified environment. BMSC charac-

Table 1. List of primers

\begin{tabular}{|c|c|c|}
\hline Gene & Forward primer & Reverse primer \\
\hline GAPDH (272 bp) & TGACCACAGTCCATGCCATCAC & СGССТGСТTСАССАССТTСТT \\
\hline COX-2 (146 bp) & TGACCACAGGCAGATGAA & CCACAGCATCGATGTCACCATAG \\
\hline IDO1 (159 bp) & GAATGGCACACGCTATGGAA & CAGACTCTATGAGATCAGGCAGATG \\
\hline IL-6 (234 bp) & СCTTCGGTCCAGTTGCСTTCTC & ССАGTGССTCTTTGCTGCTTTC \\
\hline HGF (147 bp) & GTCAGCCCTGGAGTTCCATGATA & AGCGTACCTCTGGATTGCTTGTG \\
\hline TGF $\beta \quad(130 \mathrm{bp})$ & AGCGACTCGCCAGAGTGGTTA & GCAGTGTGTTATCCCTGCTGTCA \\
\hline IL1 $\beta$ (146 bp) & GCTGAGGAAGATGCTGGTTC & GTGATCGTACAGGTGCATCG \\
\hline IL-8 (122 bp) & GACATACTCCAAАССТTTCСАССС & CCAGACAGAGCTCTCTTCCATCAG \\
\hline VEGF (150 bp) & GAGGGCAGAATCATCACGAAGTGG & ATCGCATCAGGGGCACACAGGAT \\
\hline c-Jun (242 bp) & TGGAAACGACCTTCTATGACGA & GTTGCTGGACTGGATTATCAGG \\
\hline NF- $\kappa$ B (103 bp) & TGAGTCCTGCTCCTTCCA & GCTTCGGTGTAGCCCATT \\
\hline MMP2 (169 bP) & CCGTCGCCCATCATCAAGTT & СTGTCTGGGGCAGTCCAAAG \\
\hline MMP13 (165 bp) & GCTGCСТTССТСТTCTTGA & TGCTGCATTCTCCTTCAGGA \\
\hline RANKL (196 bp) & ACCAGCATCAAAATCCCAAG & CCСCAAAGTATGTTGCATCC \\
\hline P53 (463 bp) & GCTTGCAATAGGTGTGCGTC & AAACTACCAACCCACCGACC \\
\hline IHH (247 bp) & GAACTCGCTGGCTATCTCGG & CTCGGACTTGACGGAGCAAT \\
\hline PTCH1 (298 bp) & TGTCGCACAGAACTCCACTC & ACCAAGAGCGAGAAATGGCA \\
\hline PTCH2 (431 bp) & TTACCGCAACTGGCTACAGG & CGATGGССТССАСАAАGTCT \\
\hline SP-1 (130 bp) & GGTGCCTTTTCACAGGCTC & CATTGGGTGACTCAATTCTGCT \\
\hline C-fos (280 bp) & GGATAGССTCTCTTACTACCAC & TCCTGTCATGGTCTTCACAACG \\
\hline MMP1 (199) & ACTCTGGAGTAATGTCACACC & GTTGGTCCACCTITCATCTTCA \\
\hline TNF $\alpha \quad(215$ bp) & CGAGTGACAAGCCTGTAGC & GGTGTGGGTGAGGAGCACAT \\
\hline MMP9 (139 bp) & GGGACGCAGACATCGTCATC & TCGTCATCGTCGAAATGGGC \\
\hline
\end{tabular}


teristics tests were performed using primary antibodies conjugated with fluorescein isothiocyanate (FITC), phycoerythrin (PE), or phycoerythrin-cyanin 5/7 (PC5/7) against CD14, CD34, CD45, CD73, CD90, and CD105 by Accuri C6 flow cytometer (BD Biosciences, San Jose, CA, USA). The results are shown in our previous article (22). $1 \times 10^{6}$ cells per well were stimulated with TL1A (100 $\mathrm{ng} / \mathrm{ml}$ ), and treated with $1.5 \mu \mathrm{g} / \mathrm{ml}$ TNFR2 antibodies (R\&D, USA) or recombinant IHH (rIHH) $300 \mathrm{ng} / \mathrm{ml}$ (Prospec, USA) in serum-free DMEM for $24 \mathrm{~h}$. Conditioned medium (CM) from TL1A-stimulated, non-stimulated BMSC, BMSCs with IHH siRNA and TL1A, and rIHHtreated BMSCs after incubation in serum-free DMEM for $24 \mathrm{~h}$ were collected, and $20 \%$ of CM in either RPMI-1640 or DMEM were used to incubate human $\mathrm{T}$ lymphocytes and RA-FLSs respectively. The CM is new medium added to the BMSCs cells after $24 \mathrm{~h}$ stimulation by TL1A or rIHH treatment.

\section{Flow cytometry analysis of TNFR2 expression}

Flow cytometry analysis was performed using fluo- rochrome-conjugated antibodies. Briefly, $10^{6}$ BMSCs were trypsinized and washed in PBS, and then the pellets were re-suspended in fluorescent-activated cell sorting (FACS) buffer. These single-cell suspensions were incubated in the dark at $4^{\circ} \mathrm{C}$ for $30 \mathrm{~min}$ with PE-conjugated antibodies against human TNFR2 and isotype control antibody (from eBioscience, USA). Then, the cells were centrifuged, re-suspended in PBS and analyzed using a flow cytometer (Agilent, USA). The data were collected and analyzed using the novoexpress (Agilent, USA) software (Fig. 1G).

\section{RT-PCR}

RNAiso (Takara Bio, Japan) was used to extract mRNA of BMSCs, H9 human T lymphocytes, or FLSs as described in the previous article (26). cDNA was prepared using PrimeScript ${ }^{\mathrm{TM}}$ 1st strand cDNA Synthesis Kit (Takara Bio, Japan) and $1 \mu \mathrm{g}$ of extracted mRNA. The internal control was Glyceraldehyde 3-phosphate dehydrogenase (GAPDH). Primers (Takara Bio, Japan) shown in Table 1 were used to amplify genes after being mixed with PCR MasterMix 2X Power Taq (Bio Teke

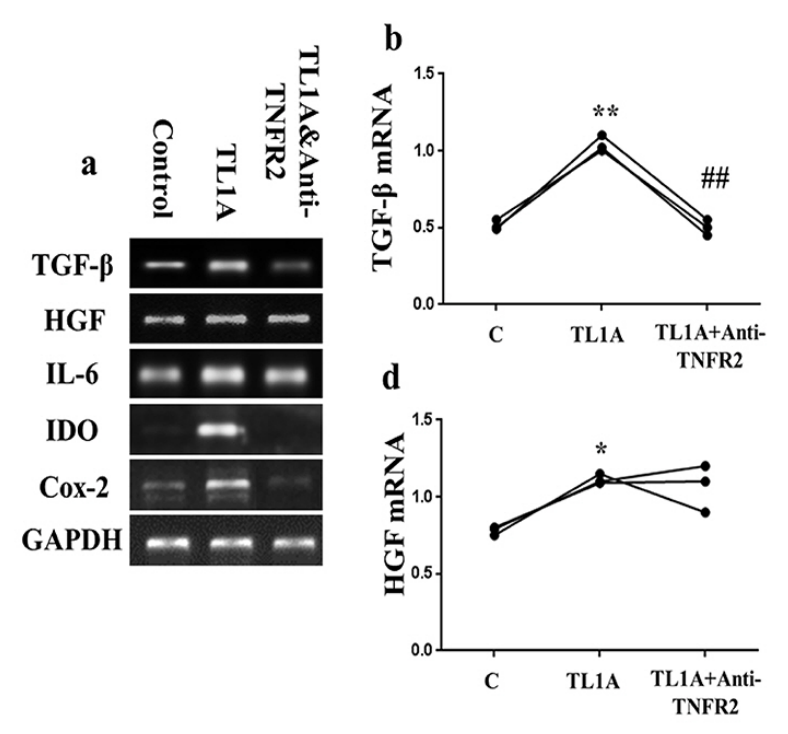

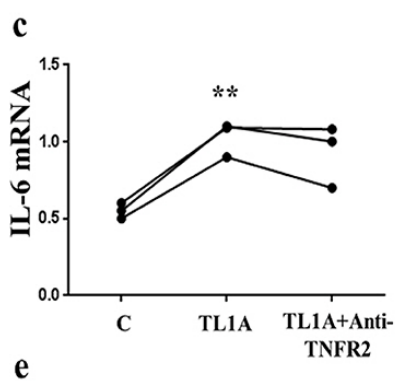

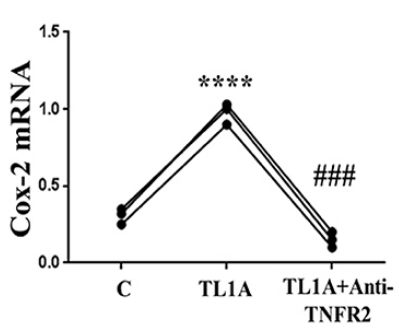

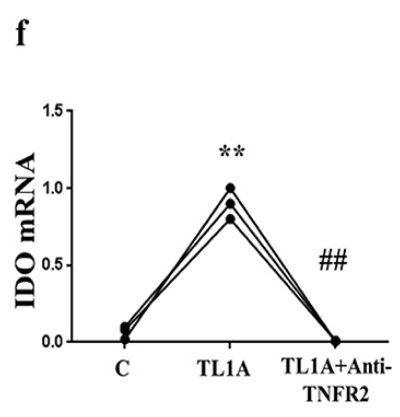
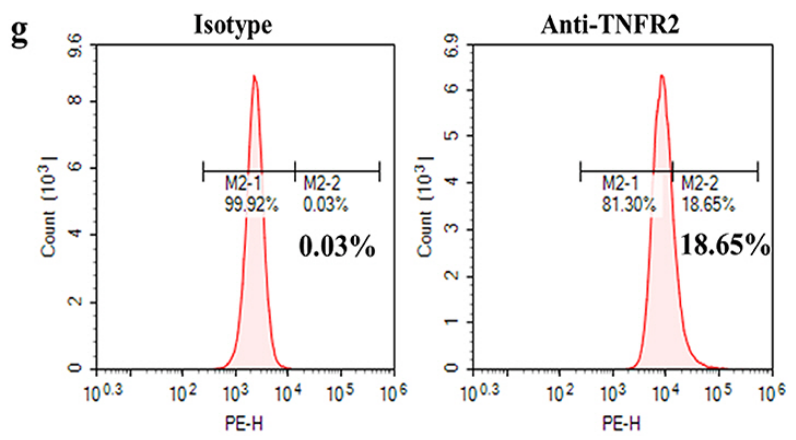

Fig. 1. TL1A induced paracrine activity of BMSCs. $(a \sim f)$ Cytokines expression in BMSCs. GAPDH used as reference. (g) The expression of TNFR2 in BMSCs. Results are representative of three independent experiment, and data presented as mean \pm SEM. ${ }^{*} \mathrm{p}<$ $0.05, * * \mathrm{p}<0.01 . * * * * \mathrm{p}<0.0001$ compared to control. ${ }^{\# \#} p<0.01$, $\# \#$ $<0.001$ compared to TL1A treatment. 
Corporation, China), cDNA, RNase Free $\mathrm{dH}_{2} \mathrm{O}$ in micro-tubes according to the manufacturer's instructions, and then incubated in the thermal cycler (Bio-Rad, USA). Each cycle consisted of $30 \mathrm{~s}$ for denaturation at $95^{\circ} \mathrm{C}, 30 \mathrm{~s}$ of annealing at $56.0,56.5,57,57.5$, or $58.0^{\circ} \mathrm{C}$, and 30 s for extension at $72^{\circ} \mathrm{C}$, for a total of 35 cycles. Electrophoresis in tris acetic acid EDTA (TAE) buffer using 2\% agarose gel was applied to separate and PCR products. Image Lab detection system (Bio-Rad, USA) or Image J (ImageJ2x, Rawak Software Inc., Germany) were used to quantify PCR bands.

\section{BMSCs in vitro bi-lineage differentiation assay}

For adipogenesis, BMSCs of $80 \%$ confluency in 24-well plate were incubated with 10\% FBS in MEM-ALPHA medium (Biological Industries, USA) and differentiation mixture containing $100 \mathrm{U} / \mathrm{ml} / 100 \mu \mathrm{g} / \mathrm{ml} \mathrm{P} / \mathrm{S}, 0.5 \mathrm{mM}$ 1-methyl-3-isobutylxanthine, $1 \mu \mathrm{M}$ dexamethasone, $10 \mu \mathrm{g} / \mathrm{ml}$ insulin, and $0.2 \mu \mathrm{M}$ indomethacin for 21 days at $37^{\circ} \mathrm{C}$ with $5 \% \mathrm{CO}_{2}$ and in humidified atmosphere. The medium was replaced every three days. Adipogenesis was assayed by the quantity of lipid or droplets accumulation which appear yellow-red after staining with Oil-Red-O lipophilic dye (Coolaber, China). $0.1 \mu \mathrm{M}$ dexamethasone, $0.05 \mathrm{mM}$ ascorbic acid, and $10 \mathrm{mM}$ glycerophosphate were added to prepare osteogenic differentiation medium. Osteogenesis was measured by the intensity of calcium deposition which stains red-orange by Alizarine-Red-S stain (Coolaber, China).

\section{BMSC colony-forming assay}

Complete medium; 10\% FBS in MEM-ALPHA and 100 $\mathrm{U} / \mathrm{ml} / 100 \mu \mathrm{g} / \mathrm{ml} \mathrm{P} / \mathrm{S}$ was used for seeding 2600 BMSCs up to 12 days at $37^{\circ} \mathrm{C} 5 \% \mathrm{CO}_{2}$ and humidity. The cells were stained by $0.2 \%$ crystal violet after being washed using PBS and fixed by $1 \%$ paraformaldehyde. Photos were taken from at least five different fields per well, and the average colony count estimated.

\section{Tranwell migration assay}

$1 \times 10^{5}$ cells/ml of BMSCs were suspended in $100 \mu 15 \%$ FBS in DMEM medium and loaded into the upper chamber of the transwell inserts of $8 \mu \mathrm{m}$ pore membrane (Costar, USA). $350 \mu 1$ chemo-attractant (20\% FBS in DMEM medium) was added to the lower chamber in a 24-well plate. The non-migrated cells were carefully removed from the inner part of the insert by a cotton-swab applicator. After $24 \mathrm{~h}$ incubation at $37^{\circ} \mathrm{C}$, and $5 \% \mathrm{CO}_{2}$, $70 \%$ ethanol was used to fix the cells for 10 minutes, and then stained with $0.2 \%$ crystal violet at $\mathrm{RT}^{\circ}$ for 20 minutes. Migrated BMSCs were counted from five random fields at 100 magnifications in each membrane.

\section{Wound healing migration assay}

A $200 \mu 1$ pipette tip was used vertically to generate wound through $100 \%$ confluency BMSCs in a 12-well plate. Cells debris were removed using culture medium and then pictures of the wound were taken at $0 \mathrm{~h}$ by an inverted microscope (Olympus 1X71, Japan). Cells were incubated at $37^{\circ} \mathrm{C}$ and $5 \% \mathrm{CO}_{2}$. Snapshots were taken after 24 hours. Evaluation of BMSCs migration was done by measuring the distance crossed by the migrated cells through the wound.

\section{ROS quantification}

ROS generation levels were measured using 2',7'Dichlorofluorescin diacetate (DCFHDA; Sigma-Aldrich, USA). $70 \%$ confluency BMSCs were incubated in DMEM with $5 \mu \mathrm{M} \mathrm{DCFHDA}$ at $37^{\circ} \mathrm{C}$ with $5 \% \mathrm{CO}_{2}$ and humidity for $30 \mathrm{~min}$. Cells were washed two times with PBS and trypsinized, and analyzed by Accuri C6 flow cytometer (BD Biosciences, San Jose, CA, USA) at $488 \mathrm{~nm}$ and 538 $\mathrm{nm}$ wavelength. In addition, stained cells were tested by fluorescence microscope (Olympus1X71, Japan) to view and capture images.

\section{Western blot}

More than $10^{6}$ harvested BMSCs were digested in a lysis buffer cocktail and centrifuged at $10000 \mathrm{xg}$ for 15 minutes at $4^{\circ} \mathrm{C}$ to get the supernatant as the total protein according to the kit protocol (KeyGen Biotech, China). $20 \mu \mathrm{g}$ of extracted protein with a loading buffer were loaded in wells of $10 \%$ sodium dodecyl sulfate-polyacrylamide gel (SDS-PAGE) for electrophoresis, and then blotted to a polyvinylidene fluoride (PVDF) membrane (Millipore Co., USA). Membranes were incubated in blocking buffer (5\% skimmed milk in tris-buffered saline tween 20, TBST,) and then with indicated primary antibodies overnight at $4^{\circ} \mathrm{C}$. After washing the primary antibodies, the membranes were incubated for $1 \mathrm{~h}$ at $\mathrm{RT}^{\circ}$ with secondary antibody conjugated with horseradish peroxidase. After TBSTwashing, the membranes were treated with enhanced chemiluminescent (ECL) reagents (Bio-Rad, USA) for imaging. Image Lab detection system (Bio-Rad, USA) was used for protein bands imaging and analysis.

\section{ELISA}

The IL-6, IL-18, IL-1 $\beta$ and IL-8 levels in the supernatants of each coculture system (BMSCs co-cultured with Jurkat T cells and BMSCs co-cultured with RA FLS) were 
measured using their respective ELISA kits (R\&D Systems, USA). All procedures were performed as described in the manufacturer's instructions. The absorbance was measured at $450 \mathrm{~nm}$. Three wells were used for each medium sample. The assays were repeated three times.

\section{Apoptosis assay}

$5 \mu 1$ fluorescein isothiocyanate-conjugated Annexin V (FITC Annexin V; BD Biosciences, USA) and $5 \mu 1$ propidium iodide (PI; BD Biosciences, USA) were used to stain 1 million washed BMSCs in $200 \mu 1 \mathrm{XX}$ Annexin V binding buffer, and then incubated for 15 minutes at $\mathrm{RT}^{\circ}$. Flow cytometry Accuri C6 (BD Biosciences, San Jose, CA, USA) was used to analyze the suspended cells.

\section{Statistical analysis}

Statistical analysis was performed using Prism 5 software (GraphPad Software Inc.). Paired sample T-test was used to compare differences between and among the group. All values are presented as means \pm SEM, and a p-value less than 0.05 was considered significant.

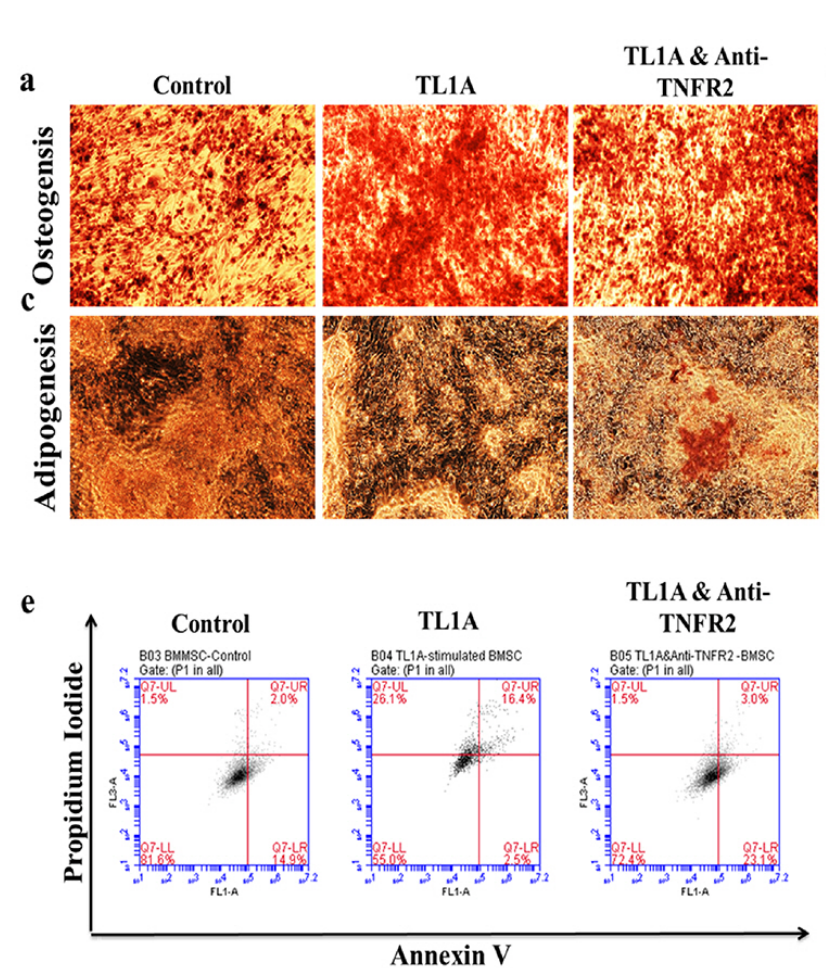

Annexin V

\section{Results}

\section{TLlA increased expressions of BMSCs paracrine-related genes}

To assess the role of TL1A on BMSCs paracrine activity, we treated the cells with $100 \mathrm{ng} / \mathrm{ml}$ TL1A or TL1A+ anti-TNFR2 and then investigated the expressions of some paracrine-related genes. TL1A significantly induced mRNA expression of COX-2, IL-6, IDO, TGF- $\beta$, and HGF in BMSCs (Fig. 1). However, when the cells were treated with TL1A+ anti-TNFR2, the increase expression of all the genes was reversed with variable significance, as the decrease in IL-6 and HGF were not statistically significant (Fig. 1C and 1D). Collectively, these findings suggest that TL1A induced the paracrine secretions of BMSCs via TNFR2.

\section{TLlA induced osteogenesis, decreased adipogenesis and has no effect on apoptosis of BMSCs}

Differentiation capacity is one of the most important characteristics which give the BMSCs the ability to regenerate tissues in cellular therapy. To investigate this property in presence of TL1A, we incubated BMSCs in adipogenic and osteogenic differentiation media after treatment with TL1A or TNFR2. Differentiation was measured by Alizarin Red S staining for osteogenic differ-
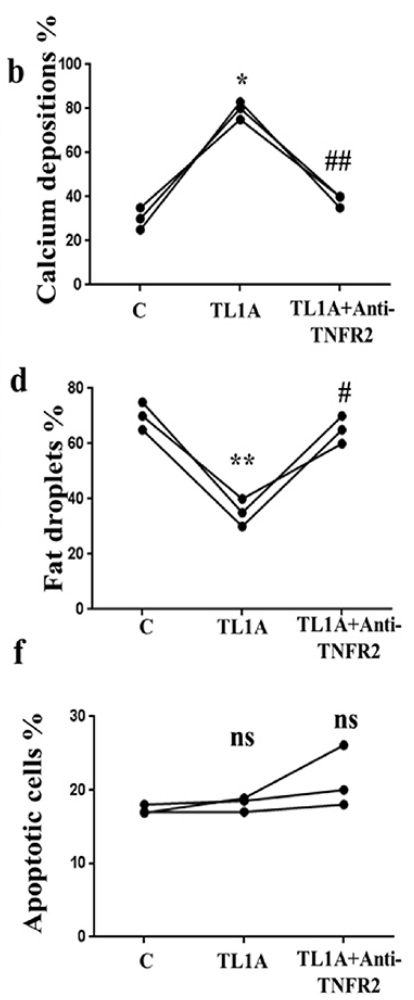

Fig. 2. TL1A promoted osteogenic differentiation at the cost of adipogenic differentiation. ( $a$, b) Osteogenic stain and measure of stain intensity. (c, d) Adipogenic stain and measure of stain intensity. $(\mathrm{e}, \mathrm{f})$ Flow cytometry of cells apoptosis and apoptotic cells percentages. Data presented as mean \pm SEM from three independent experiments. ns $>0.05$, ${ }^{*} \mathrm{p}<0.05,{ }^{* *} \mathrm{p}<0.01$ compared to control. ${ }^{*} p<0.05, \# p<0.01$ compared to TL1A treatment. 
entiation and Oil Red $\mathrm{O}$ for adipogenic differentiation. TL1A increased osteogenesis shown by increased red-orange calcium depositions, but anti-TNFR2 decreased this surge (Fig. 2A and 2B). Experiments of adipogenic differentiation revealed that TL1A inhibited adipogenesis indicated by decreasing yellow-red fat droplet, whereas anti-TNFR2 treatment restored this inhibition (Fig. 2C and 2D). In other experiments, TL1A was not affect the survival of BMSCs through TNFR2 (Fig. 2E and 2F). Our results revealed that TL1A could correct the biased differentiation of BMSCs to favor osteogenesis.

\section{TL1A enhanced BMSCs proliferation and migration}

Proliferation and migration of BMSCs are the main properties in the therapeutic activities MSC. Thus, colony formation assay, and transwell and wound closure assays were applied to measure the roles of TL1A on BMSCs proliferation and migration. The results of the CFU showed an increased count of colonies after 12 days of treatment and continuous culture of BMSCs treated with TL1A. However, the colony count was reversed after treatment with anti-TNFR2. (Fig. 3A and 3B). Interestingly, the results of cell migration revealed that TL1A significantly increased migrated cells in the transwell experiments (Fig. 3C and 3D) and the speed of cells in the wound healing assay (Fig. 3E and 3F). More importantly, treatment of
BMSCs with anti-TNFR2 in the presence of TL1A decreased the migration ability. These observations indicate that TL1A enhances BMSCs' biological activities through promoting both proliferation and migration via TNFR2.

\section{TLlA-stimulated BMSCs conditioned medium has an anti-inflammatory effect on human $\mathrm{T}$ lymphocytes and FLSs from rheumatoid arthritis patients}

To assess the effect of TL1A induced stimulation on the therapeutic efficiency of BMSCs, we incubated H9 T cells and RA-FLSs with conditioned medium collected from TL1A-stimulated BMSCs (TL1A stimulated-BMSC-CM) or without TL1A (BMSC-CM). In H9 T cells, genes expressions of inflammatory markers, IL-6, IL-8, TNF $\alpha$, MMP2, MMP9, C-fos, C-Jun, and Sp-1 were down-regulated significantly by TL1A stimulated-BMSC-CM coupled with mild down-regulation of IL-1 $\beta$, RANKL, and COX2 expressions (Fig. 4A L ). Also, ELISA results showed that TL1A stimulated-BMSCs-CM suppressed inflammatory cytokines; IL-6, IL-18, IL- $\beta$, and IL-8 in jurkat $\mathrm{T}$ lymphocytes (Fig. $4 \mathrm{M} \sim \mathrm{P}$ ). In RA-FLS, RT-PCR results showed down-regulation in expressions of RANKL, COX2, MMP1, MMP2, MMP9, MMP13 and, C-Jun following treatment with TL1A stimulated-BMSC-CM. However, genes transcription of NF-kB and VEGF assay revealed undetectable bands with TL1A stimulated-

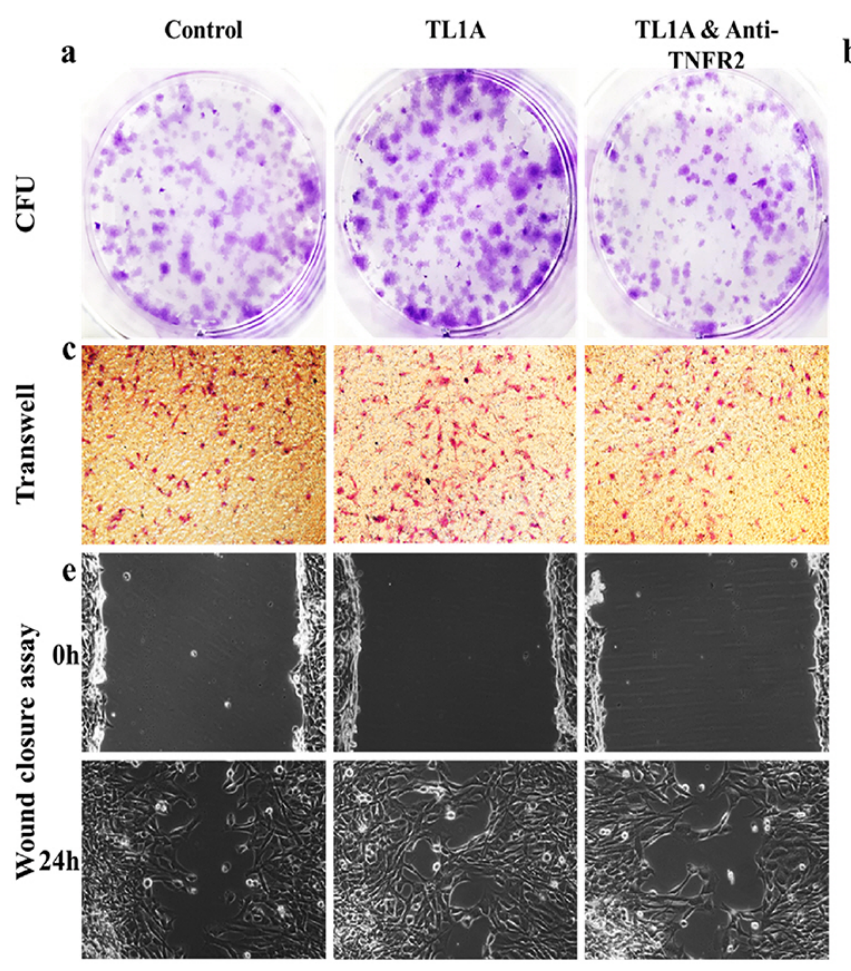

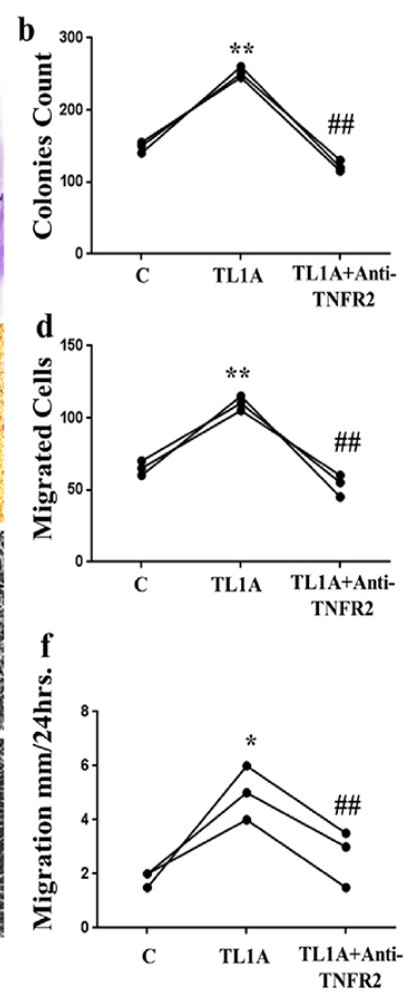

Fig. 3. TL1A promoted BMSCs proliferation and migration. $(\mathrm{a}, \mathrm{b})$ Colony forming assay after 12 days of treatments and continuous culture. (c, d) Transwell migration assay after $24 \mathrm{~h}$ of treatment. (e, f) Wound healing assay for $0 \mathrm{~h}$ and $24 \mathrm{~h}$ after scratch. Results are representative of three independent experiment, and data presented as mean \pm SEM. ${ }^{*} p<0.05$, $* * \mathrm{p}<0.01$ compared to control. $\# p<0.05, \# p<0.001$ compared to TL1A treatment. 


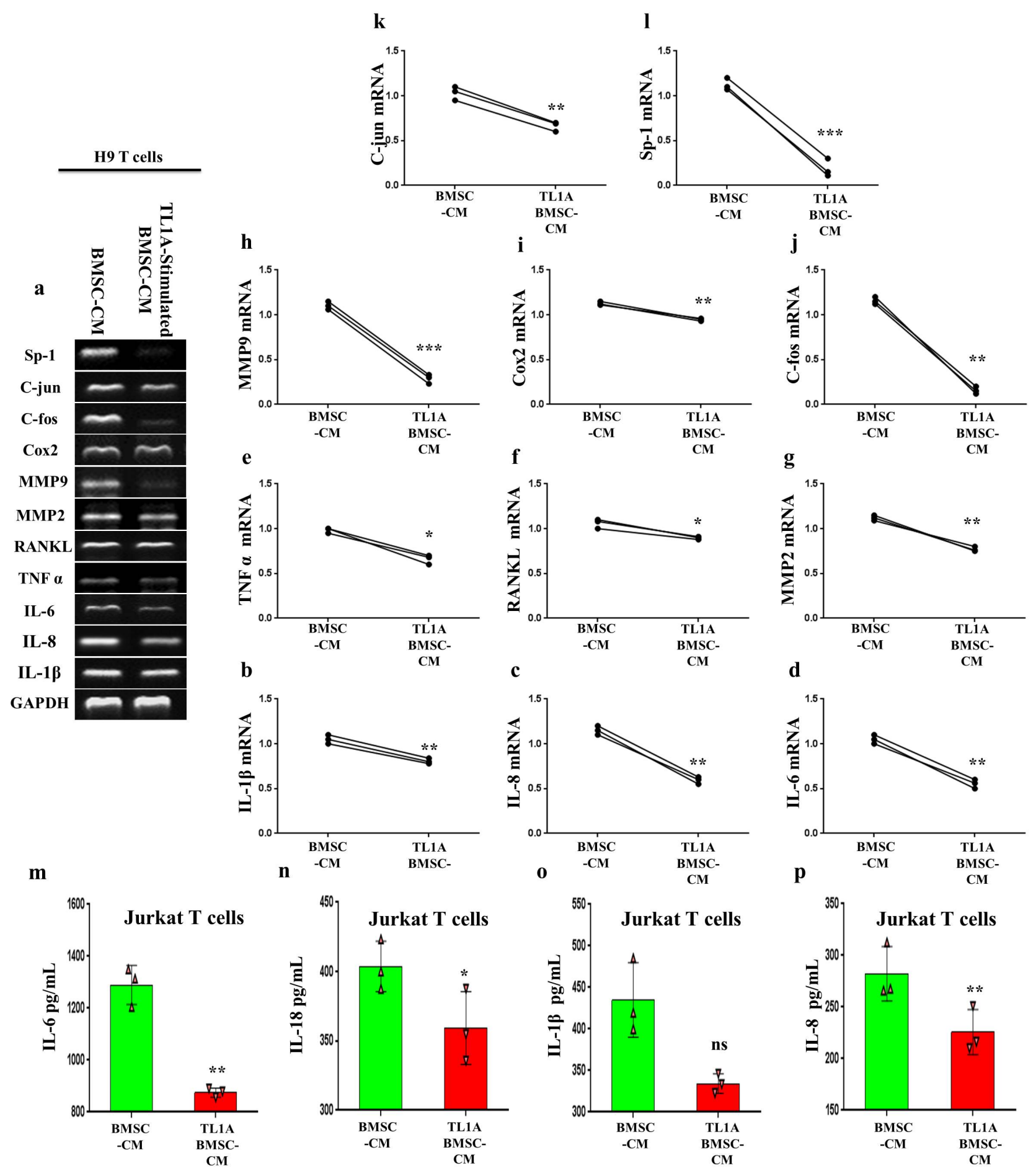

Fig. 4. TL1A increased anti-inflammatory effect of BMSCs on human T cells. Representative RT-PCR bands and quantification of inflammatory cytokines expressed by H9 T cells $(\mathrm{a} \sim \mathrm{l})$. GAPDH used as reference. $(\mathrm{m} \sim \mathrm{p}) \mathrm{IL}-6, \mathrm{IL}-18, \mathrm{IL}-1 \beta$, and IL-8 levels in jurkat T cells measured by ELISA. Results are representative of three independent experiment, and data presented as mean \pm SEM. ns $>0.05,{ }^{*} p<0.05,{ }^{* *} p<0.01$, $* * * \mathrm{p}<0.001$ compared to BMSC-CM.

BMSC-CM treatment (Fig. 5A $\sim$ J). In accordance with these data, checking the levels of inflammatory cytokines; IL-6, IL-18, IL-1 $\beta$, and IL-8 by ELISA revealed anti-in- flammatory effect for TL1A stimulated-BMSC-CM (Fig. $5 \mathrm{~K} \sim \mathrm{N})$. These findings suggest TL1A could promote BMSCs' ability in alleviating inflammation in patients 


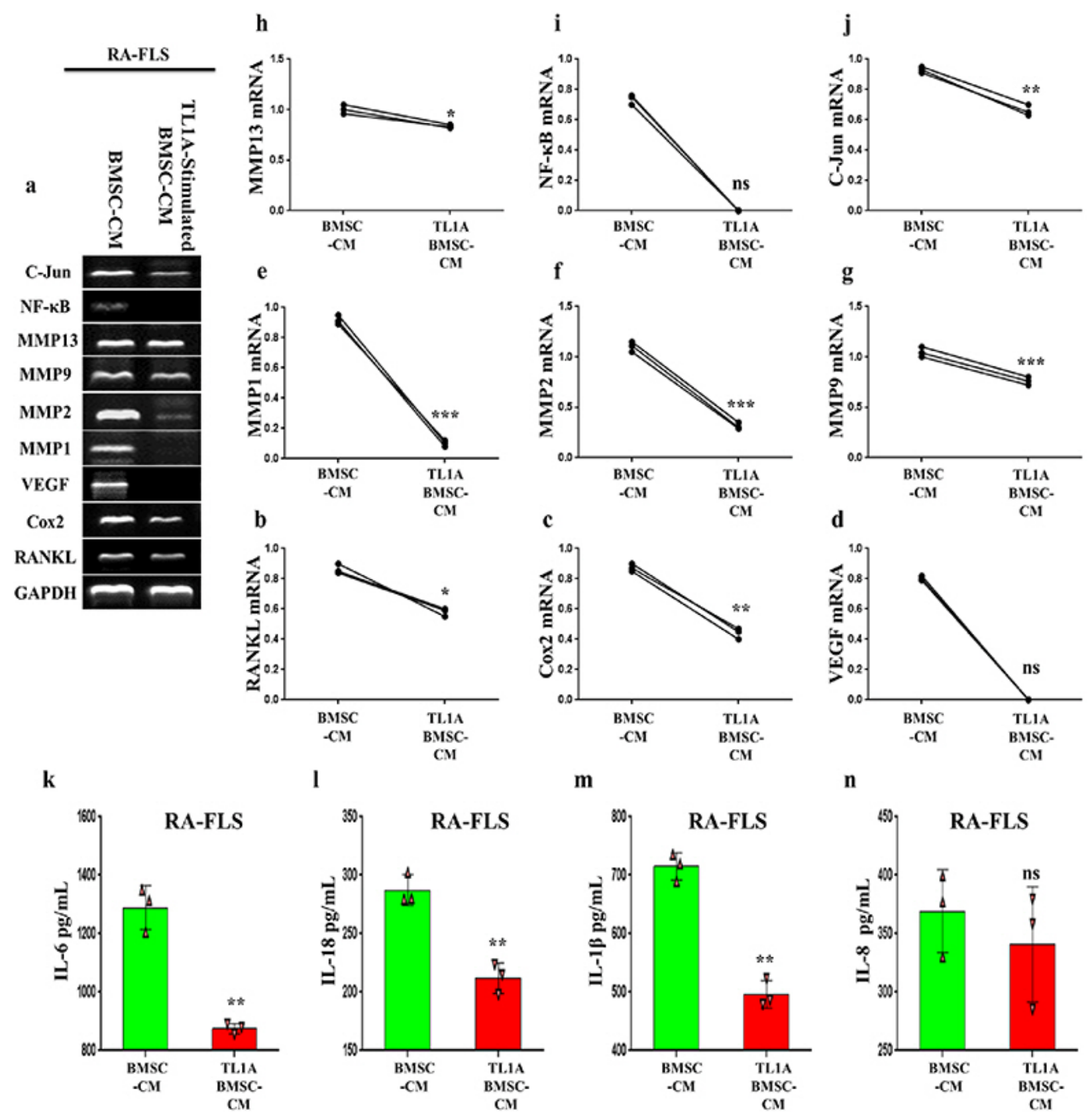

Fig. 5. TL1A induced BMSCs anti-inflammatory effect on FLSs from rheumatoid arthritis patients. Representative RT-PCR bands and quantification of inflammatory cytokines expressed by RA-FLSs $(\mathrm{a} \sim \mathrm{j})$. GAPDH used as reference. $(\mathrm{k} \sim \mathrm{n}) \mathrm{IL}-6, \mathrm{IL}-18, \mathrm{IL}-1 \beta$, and IL-8 levels in RA-FLSs cells measured by ELISA. Results are representative of three independent experiment, and data presented as mean $\pm \mathrm{SEM}$. $\mathrm{ns}>0.05,{ }^{*} \mathrm{p}<0.05$, $* * \mathrm{p}<0.01, * * * \mathrm{p}<0.001$ compared to BMSC-CM.

with inflammation, for example RA patients.

\section{TLlA-promoted IHH associated with NF- $\kappa$ B and} STAT3 signaling up-regulation, and p53 and oxidative stress down-regulation in BMSCs

To investigate how TL1A activate BMSCs, we decided to assay IHH pathway due to its importance in MSCs po- tency (22), and because our previous results discovered that TL1A can regulate IHH pathway in FLSs (25). Surprisingly, results of RT-PCR experiments showed that TL1A promotes transcription of IHH ligand and its trans-membranous receptors, $\mathrm{PTCH} 1 / 2$, but reversed by anti-TNFR2 in BMSCs (Fig. $6 \mathrm{E} \sim \mathrm{G}$ ). Also, IHH translation was assayed by western blot, and consistently; the 
results presented increased IHH protein after TL1A stimulation and decreased due to anti-TNFR2 treatment (Fig. $6 \mathrm{~A}$ and $6 \mathrm{D})$. In further experiments, we assessed the activity of NF-k $\beta$, STAT3, p53, and ROS signaling because of their importance in BMSCs stemness and association with $\mathrm{HH}$ signaling. Results of the western blot assay revealed up-regulation of $\mathrm{p} 65-\mathrm{NF}-\mathrm{k} \beta$, and $\mathrm{p}$-STAT3 through TL1A/TNFR2 axis (Fig. 6B and 6C). However, RT-PCR results of p53 displayed down-regulation by TL1A stimulation but not through TNFR2 (Fig. 6E and 6H). Additionally, stimulation of BMSCs by TL1A decreased ROS generation (Fig. 6I $\sim \mathrm{K}$ ). These findings suggest an important role for $\mathrm{IHH}$ signaling in the effects exerted by TL1A on BMSCs stemness. For further confirmation, we used $\mathrm{rIHH}$ protein to explore the role of $\mathrm{IHH}$ in BMSCs stemness. BMSCs were treated with $\mathrm{rIHH}$ and incubated
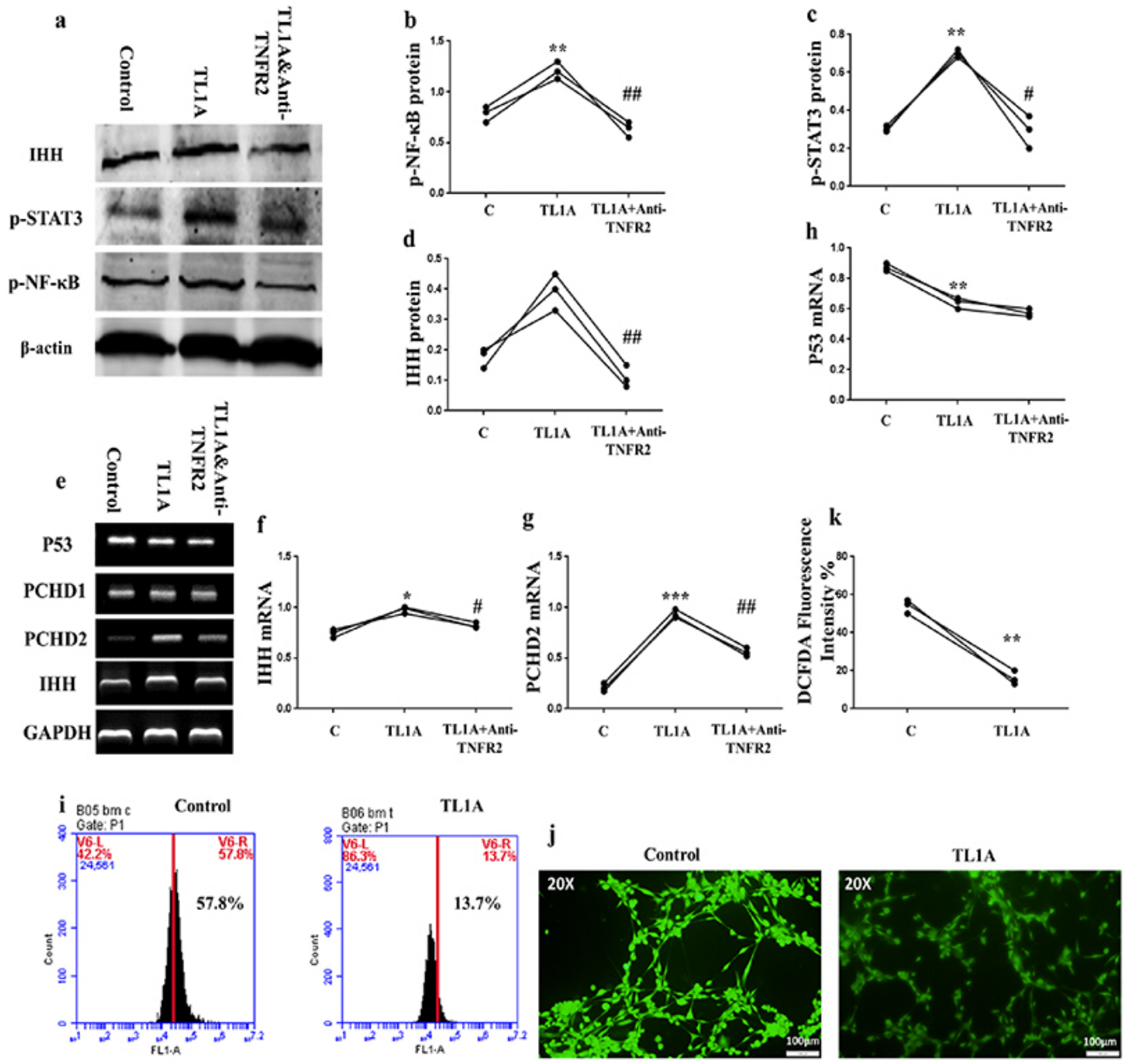

Fig. 6. TL1A modulated IHH expression and stemness-related signaling pathways in BMSCs. $(\mathrm{a} \sim \mathrm{d})$ Representative western blot bands and relative band intensity of p65-NF-k $\beta$, p-STAT3, and IHH. $(\mathrm{e} \sim \mathrm{h})$ PCR bands and estimation of mRNA expression of some aging-related genes. $\beta$-actin and GAPDH used as references. ( $\sim$ k) Representative flow cytometry and microscopic (at 20X magnification) images and quantification of ROS generation. Results are representative of three independent experiment, and data presented as mean \pm SEM. ${ }^{*} \mathrm{p}<0.05$, ${ }^{* *} \mathrm{p}<0.01,{ }^{* * *} \mathrm{p}<0.001,{ }^{* * * *} \mathrm{p}<0.0001$ compared to control. ${ }^{\#} \mathrm{p}<0.05,{ }^{\#} \mathrm{p}<0.001$ compared to TL1A treatment. 
for $24 \mathrm{~h}$ before collection of rIHH-treated BMSC-CM. After incubation of jurkat $\mathrm{T}$ lymphocytes and RA-FLSs with rIHH-treated BMSC-CM for $24 \mathrm{~h}$, we found that IL-18, IL-1 $\beta$, and IL-8 cytokines levels were compromised in both cells (Fig. 7).

\section{IHH is involved in TLlA-dependent BMSCs immunomodulation promotion}

To evaluate the interaction of TL1A with IHH in the therapeutic potency of BMSCs, we used IHH siRNA to silence IHH gene and prepared conditioned medium in the presence of TL1A (TL1A-BMSC $\left.{ }^{-\mathrm{IHH}}-\mathrm{CM}\right)$. The efficiency of IHH was assessed by RT-PCR, western blot and FAM negative control (22). The control group's conditioned medium was TL1A-stimulated BMSCs with negative control siRNA (Control-CM). After incubating H9 $\mathrm{T}$ cells with the two conditioned media, we assayed for the gene expression of some inflammatory mediators; IL-1 $\beta$, IL-8, RANKL, TNF $\alpha, M M P 1, M M P 13$, and COX2. Interestingly, we observed that $\mathrm{H} 9 \mathrm{~T}$ cells treated with TL1ABMSC $^{-\mathrm{IHH}}-\mathrm{CM}$ expressed the inflammatory mediators (Fig. $8 \mathrm{~A} \sim \mathrm{D}, \mathrm{F} \sim \mathrm{H}$ ) significantly more than the $\mathrm{H} 9 \mathrm{~T}$ cells treated with Control-CM except for MMP13 (Fig. 8A and $8 \mathrm{E}$ ) which showed no difference between the groups. In addition, incubation of RA-FLSs with conditioned medium of the control and BMSCs with IHH siRNA revealed increased expression of IL-6, RANKL, C-fos and Sp-1 inflammatory molecules in TL1A-BMSC ${ }^{-\mathrm{IHH}}-\mathrm{CM}$ groups compared to control groups (Fig. $8 \mathrm{I} \sim \mathrm{M}$ ). The findings indicated that TL1A may play a role in increasing BMSCs stemness through IHH signaling, as IHH-depleted BMSCs failed to inhibit inflammation in $\mathrm{H} 9 \mathrm{~T}$ cells and FLSs of $\mathbf{a}$
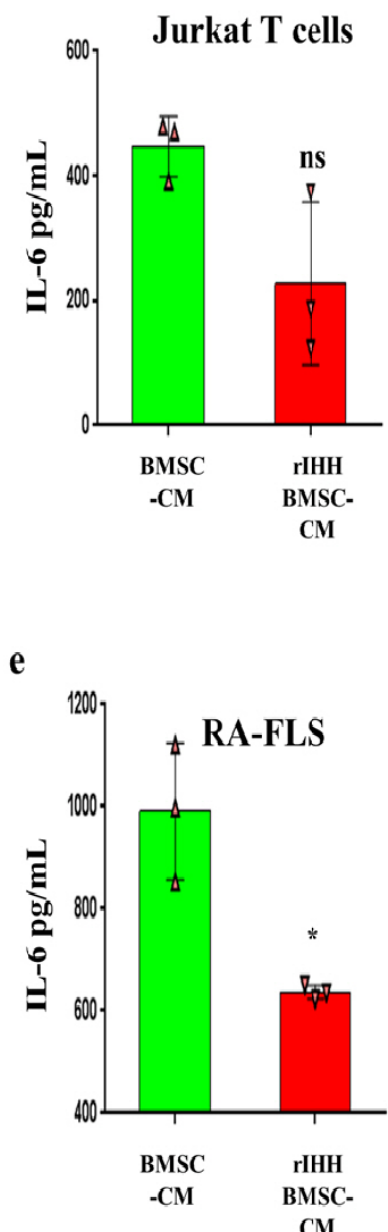

b

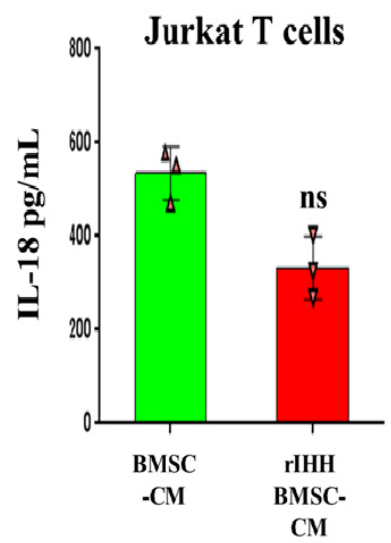

f

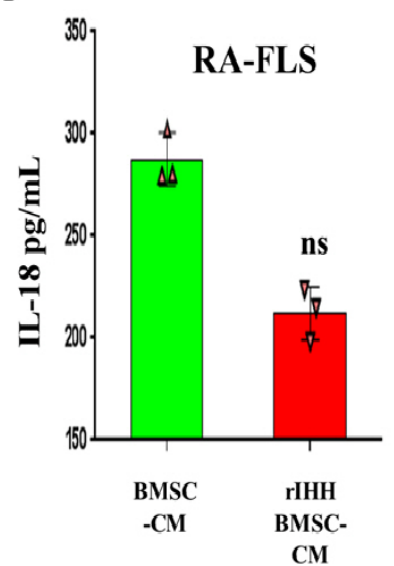

c

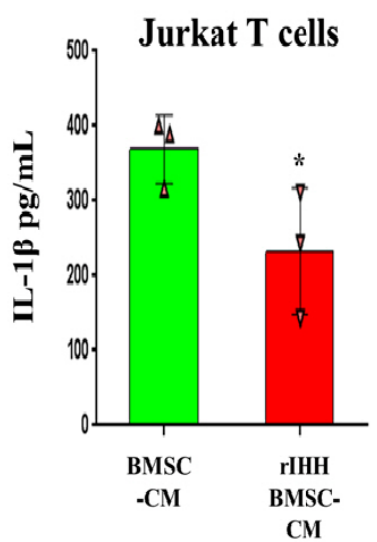

g

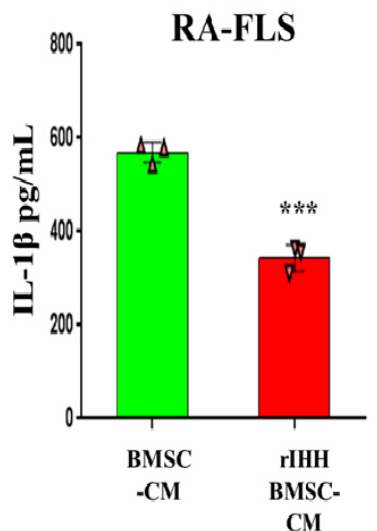

d

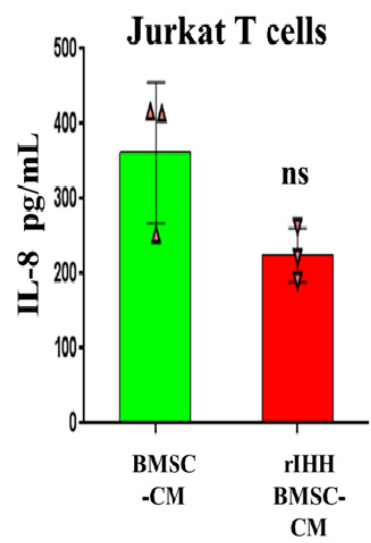

$\mathbf{h}$

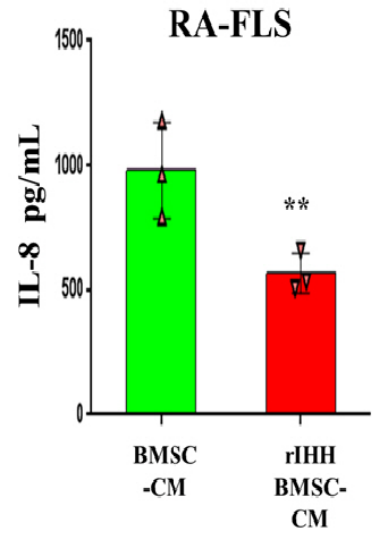

Fig. 7. IHH induced anti-inflammatory power of BMSCs. (a $\sim$ d) IL-6, IL-18, IL-1 $\beta$, and IL-8 levels in jurkat T cells measured by ELISA. $(\mathrm{e} \sim \mathrm{h})$ IL-6, IL-18, IL-1 $\beta$, and IL-8 levels in RA-FLSs cells measured by ELISA. Results are representative of three independent experiment, and data presented as mean \pm SEM. ns $>0.05,{ }^{*} p<0.05,{ }^{* *} p<0.01,{ }^{* * *} p<0.001$ compared to BMSC-CM. 


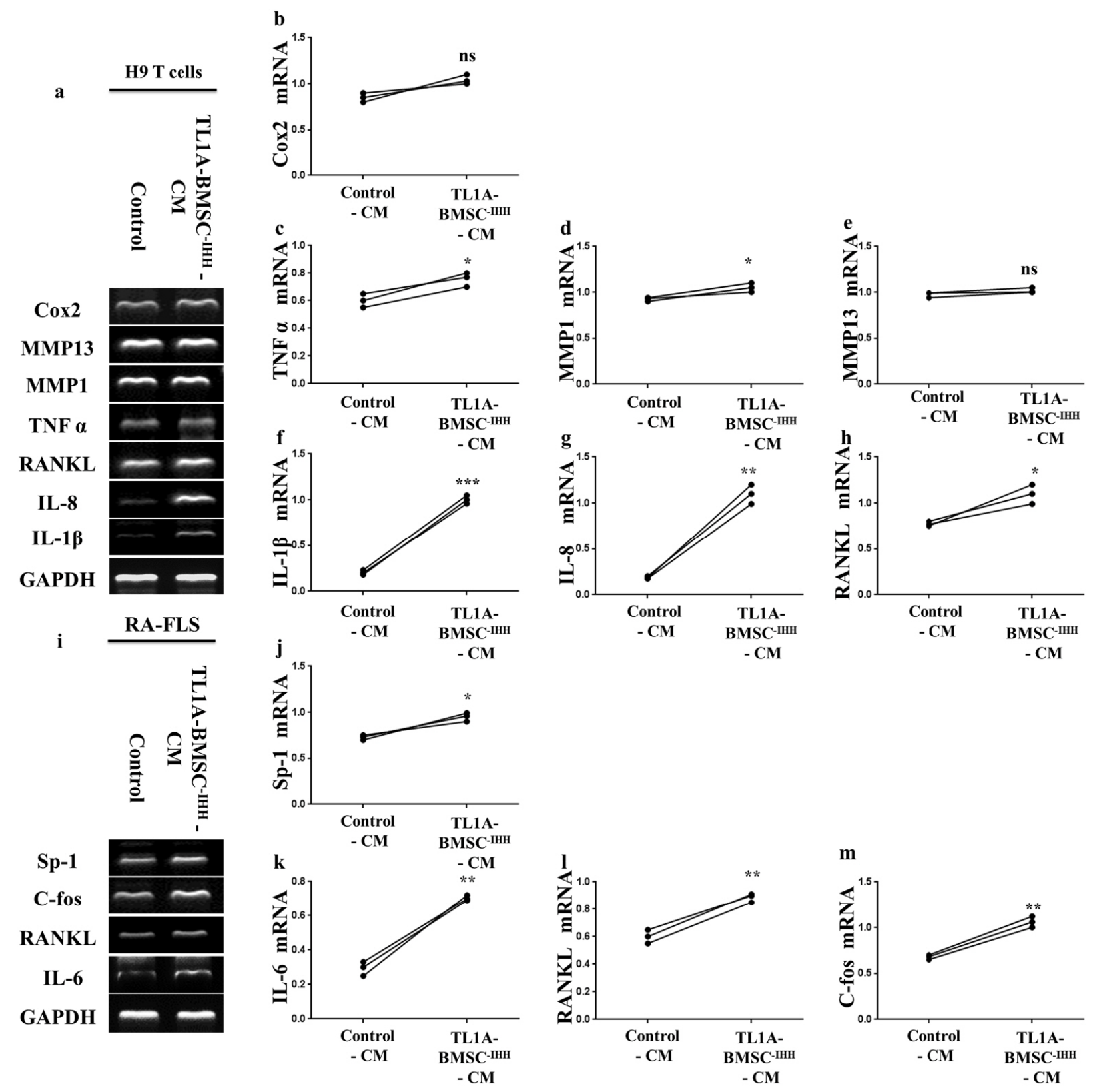

Fig. 8. Effect of TL1A-BMSCs ${ }^{-I H H}$ conditioned medium on $\mathrm{H} 9 \mathrm{~T}$ cells and FLSs from rheumatoid arthritis patients. Representative RT-PCR bands and quantification of inflammatory mediators expressed by H9 T cells $(a \sim h)$, and RA-FLS $(i \sim m)$. GAPDH used as reference. Results are representative of three independent experiment, and data presented as mean \pm SEM. ns $>0.05, * p<0.05,{ }^{* *} p<0.01,{ }^{* * *} p<0.001$ compared to BMSC-CM.

rheumatoid arthritis patients despite the presence of TL1A.

\section{Discussion}

This study revealed an activation effect of TL1A on BMSCs in which the paracrine parameters, COX-2, IL-6, IDO, TGF- $\beta$, and HGF were induced after treatment with TL1A and reversed by anti-TNFR2 antagonist. These genes are closely related to the paracrine activity of BMSCs, and the findings suggest that TL1A could promote the immunoregulatory capacity of BMSCs. In a previous study, it was shown that preconditioning MSCs with IL-1 $\beta$ suppressed LPS-induced inflammation in microglial cells via IL-1 receptor typel (IL-1R1) and granulocyte-colony stimulating factor (G-CSF) (27). Also, stim- 
ulation of BMSCs with IL-1 $\beta$ and IFN- $\gamma$ modulated macrophage polarization and promoted its anti-inflammatory ability (28), while human amnion-derived MSCs enhanced the functions of rat ovaries through their paracrine secretions including HGF (29).

TL1A/TNFR2 axis promoted BMSCs differentiation toward osteogenesis at the cost of adipogenic differentiation, and enhanced proliferation and migration. Such observations introduce new proof in TL1A's ability to support BMSCs in the treatment of bone-loss diseases. Another cytokine from the same family, TNF- $\alpha$ promoted adverse microRNAs expression in MSCs exosomes (30), and induced bone regeneration and immunoregulatory potency following TNF- $\alpha$ and IFN- $\gamma$ preconditioning (31). On the other hand, this study showed that TL1A cannot change apoptotic cells counts after stimulation of BMSCs in cell culture. Conversely, another cytokine, IL-8 was reported as a protector for BMSCs which supported their proliferation through decreased apoptotic cells percentage by Akt-STAT3 pathway (32). Furthermore, BMSCs treated with IL-8 displayed enhanced therapeutic potency in bone formation characterized by osteogenesis and chondrogenesis up-regulation by activating PI3K/Akt pathway in CXCR2-dependent manner (33). It has also been reported that MSCs migration could be stimulated through cytokines (34). Seemingly, TL1A enhances BMSCs stemness through correcting biased differentiation and increasing proliferation and migration.

Our results showed that TL1A induced IHH, NF- $\kappa \mathrm{B}$, and STAT3 pathways and down-regulated p53 and ROS in BMSCs. In addition, the conditioned medium of TL1A-stimulated BMSCs has an anti-inflammatory effect on inflammatory cells derived from RA patients. Consequently, this study uncovered that TL1A promoted BMSCs immunomodulatory potency through IHH signaling pathway. Compatible with our observations, pretreatment of BMSCs with IFN- $\gamma$ mediated their suppressing power on activated lymphocytes (35) through increased expression of immunosuppressive molecules, TGF- $\beta$, HGF, and PGE2 (36). Meanwhile, a core player in aging, P53, may have an effective interaction with hedgehog signaling (37) and this may have direct contributions to the senescence process and stemness of BMSCs. IHH, a hedgehog homolog related to cartilage and bone formation is considered an inducer in chondrogenesis of human MSC (38). Going on, NF- $\kappa$ B-mediated IL-4 increased the anti-inflammatory property of BMSCs (39), and an engineered MSCs was reported to have a good influence in the treatment of autoimmune inner ear inflammation through overexpressing of IL-4 (40). Besides, IL-7 promoted renal regeneration by enhancing the fusion ability of rat BMSCs (41). Moreover, IL-17-stimulated MSCs increased survival of skin transplant from allogenic source (42), and IL-17a-pretreated MSCs characteristically increased the therapeutic efficiency in renal diseases (43), whereas IL-17b promoted the immunoregulatory potency of MSCs in the treatment of gastric diseases (44). IL-22 promoted MSCs migration, proliferation, and osteogenic differentiation (45). Moreover, IL-23 may have a role in promoting MSCs immunoregulatory ability in the treatment of autoimmune disease through up-regulation of IL-10 and down-regulation of IL-17 in an inflammatory niche (46).

Conditioned medium derived from MSCs is used in clinical applications due to its anti-inflammatory, antioxidant, and regenerative ability. It is believed that the therapeutic potential of MSCs' conditioned medium is attributed to the secretion of exosomes which contain regulatory molecules of MSCs, cytokines and another paracrine secretome (47). In this study, we found increased expressions of IL- $1 \beta$, IL- 8 , RANKL, TNF $\alpha$, MMP1, and COX2 genes in H9 $\mathrm{T}$ cells treated with TL1ABMMSC $^{-\mathrm{IHH}}-\mathrm{CM}$ when compared to Control-CM control groups. Moreover, incubation of RA-FLSs with TL1ABMMSC $^{-\mathrm{IHH}}-\mathrm{CM}$ revealed increased expressions of IL-6, RANKL, C-fos, and Sp-1 genes more than in RA-FLSs treated with Control-CM. Our results explored that knockdown of IHH led to attenuation of BMSCs immunoregulatory ability despite stimulation by TL1A. Consistently, it has been reported that interrupting cellular signaling may decline the MSCs immunomodulatory potency and accelerate cellular senescence. For example, Mateos et al reported that knockdown of lamin A in MSCs mediates impairments in their differentiation potential (48). Also, MSCs osteogenic differentiation was inhibited through beta-catenin deacetylation inhibition after deletion of SIRT1 (49). Besides, FGF2 interruption in MSCs from bone marrow accelerating aging signs such as increased adipogenic differentiation and decreased osteogenic differentiation (50). Taken together, the activity of TL1A on signaling, differentiation, paracrine secretions, migration, and proliferation of BMSCs is maybe regulated through IHH signaling.

\section{Conclusion}

In summary, TL1A/TNFR2 interaction induced paracrine activity, migration, and proliferation in BMSCs. In addition, TL1A promoted BMSCs osteogenic differentiation at the cost of adipogenic differentiation. Moreover, this study suggests a possible role for IHH signaling path- 
way in anti-inflammatory ability of TL1A-stimulated BMSCs. These findings introduce a novel approach in cellular therapy to enhance the therapeutic potency of MSCs.

\section{Acknowledgments}

This research was funded by National Natural Science Foundation of China (81671606, 81801609); China International Medical Foundation and Rheumatoid Special Fund (Z-2018-40); The Natural Science Foundation of Liaoning Province of China (20180550662); College Scientific Research Project of Education Department of Liaoning Province (LQ2017004); Liaoning Distinguished Professor (Liao taught (2018-2020)). Dalian key laboratory of human homeostasis microbiology and disease immunology.

\section{Potential Conflict of Interest}

The authors have no conflicting financial interest.

\section{Author Contributions}

MA, WW, XL and BW conceived and designed the study. MAL, JW, WL, YT, XW, AS, EEA, SA, MAW assisted in laboratory experiments. MA, WW, MAL, JW, WL, BW, YT, MAW aided in data analysis. MA and WW drafted the manuscript. XL and BW supervised the study. All authors read and approved the manuscript.

\section{References}

1. Friedenstein AJ, Gorskaja JF, Kulagina NN. Fibroblast precursors in normal and irradiated mouse hematopoietic organs. Exp Hematol 1976;4:267-274

2. Prockop DJ. Marrow stromal cells as stem cells for nonhematopoietic tissues. Science 1997;276:71-74

3. Pittenger MF, Mackay AM, Beck SC, Jaiswal RK, Douglas R, Mosca JD, Moorman MA, Simonetti DW, Craig S, Marshak DR. Multilineage potential of adult human mesenchymal stem cells. Science 1999;284:143-147

4. Smith JR, Pochampally R, Perry A, Hsu SC, Prockop DJ. Isolation of a highly clonogenic and multipotential subfraction of adult stem cells from bone marrow stroma. Stem Cells 2004;22:823-831

5. Jiang Y, Jahagirdar BN, Reinhardt RL, Schwartz RE, Keene CD, Ortiz-Gonzalez XR, Reyes M, Lenvik T, Lund T, Blackstad M, Du J, Aldrich S, Lisberg A, Low WC, Largaespada DA, Verfaillie CM. Pluripotency of mesenchymal stem cells derived from adult marrow. Nature 2002;418:41-49

6. Krampera M, Franchini M, Pizzolo G, Aprili G. Mesenchymal stem cells: from biology to clinical use. Blood Transfus 2007;5:120-129
7. Nagamura-Inoue T, Mukai T. Umbilical cord is a rich source of mesenchymal stromal cells for cell therapy. Curr Stem Cell Res Ther 2016;11:634-642

8. Koç ON, Gerson SL, Cooper BW, Dyhouse SM, Haynesworth SE, Caplan AI, Lazarus HM. Rapid hematopoietic recovery after coinfusion of autologous-blood stem cells and cultureexpanded marrow mesenchymal stem cells in advanced breast cancer patients receiving high-dose chemotherapy. J Clin Oncol 2000;18:307-316

9. Burks SR, Nagle ME, Bresler MN, Kim SJ, Star RA, Frank JA. Mesenchymal stromal cell potency to treat acute kidney injury increased by ultrasound-activated interferon- $\gamma /$ interleukin-10 axis. J Cell Mol Med 2018;22:6015-6025

10. Gurung S, Williams S, Deane JA, Werkmeister JA, Gargett $\mathrm{CE}$. The transcriptome of human endometrial mesenchymal stem cells under TGF $\beta \mathrm{R}$ inhibition reveals improved potential for cell-based therapies. Front Cell Dev Biol 2018;6:164

11. Le Blanc K, Tammik L, Sundberg B, Haynesworth SE, Ringdén O. Mesenchymal stem cells inhibit and stimulate mixed lymphocyte cultures and mitogenic responses independently of the major histocompatibility complex. Scand J Immunol 2003;57:11-20

12. Migone TS, Zhang J, Luo X, Zhuang L, Chen C, Hu B, Hong JS, Perry JW, Chen SF, Zhou JX, Cho YH, Ullrich S, Kanakaraj P, Carrell J, Boyd E, Olsen HS, Hu G, Pukac L, Liu D, Ni J, Kim S, Gentz R, Feng P, Moore PA, Ruben SM, Wei P. TL1A is a TNF-like ligand for DR3 and TR6/DcR3 and functions as a $\mathrm{T}$ cell costimulator. Immunity 2002;16:479-492

13. Meylan F, Davidson TS, Kahle E, Kinder M, Acharya K, Jankovic D, Bundoc V, Hodges M, Shevach EM, Keane-Myers A, Wang EC, Siegel RM. The TNF-family receptor DR3 is essential for diverse $\mathrm{T}$ cell-mediated inflammatory diseases. Immunity 2008;29:79-89

14. Ma Z, Wang B, Wang M, Sun X, Tang Y, Li M, Li F, Li $\mathrm{X}$. TL1A increased IL-6 production on fibroblast-like synoviocytes by preferentially activating TNF receptor 2 in rheumatoid arthritis. Cytokine 2016;83:92-98

15. Siakavellas SI, Bamias G. Tumor necrosis factor-like cytokine TL1A and its receptors DR3 and DcR3: important new factors in mucosal homeostasis and inflammation. Inflamm Bowel Dis 2015;21:2441-2452

16. Matsumura E, Tsuji K, Komori K, Koga H, Sekiya I, Muneta T. Pretreatment with IL-1 $\beta$ enhances proliferation and chondrogenic potential of synovium-derived mesenchymal stem cells. Cytotherapy 2017;19:181-193

17. Chen MS, Lin CY, Chiu YH, Chen CP, Tsai PJ, Wang HS. IL-1 $\beta$-induced matrix metalloprotease-1 promotes mesenchymal stem cell migration via PAR1 and G-protein-coupled signaling pathway. Stem Cells Int 2018;2018:3524759

18. Putra A, Ridwan FB, Putridewi AI, Kustiyah AR, Wirastuti $\mathrm{K}$, Sadyah NAC, Rosdiana I, Munir D. The role of TNF- $\alpha$ induced MSCs on suppressive inflammation by increasing TGF- $\beta$ and IL-10. Open Access Maced J Med Sci 2018;6: $1779-1783$ 
19. Katoh Y, Katoh M. WNT antagonist, SFRP1, is Hedgehog signaling target. Int J Mol Med 2006;17:171-175

20. Ingham PW, McMahon AP. Hedgehog signaling in animal development: paradigms and principles. Genes Dev 2001; 15:3059-3087

21. Kawagishi H, Xiong J, Rovira II, Pan H, Yan Y, Fleischmann BK, Yamada M, Finkel T. Sonic hedgehog signaling regulates the mammalian cardiac regenerative response. J Mol Cell Cardiol 2018;123:180-184

22. Al-Azab M, Wang B, Elkhider A, Walana W, Li W, Yuan B, Ye Y, Tang Y, Almoiliqy M, Adlat S, Wei J, Zhang Y, Li X. Indian Hedgehog regulates senescence in bone marrow-derived mesenchymal stem cell through modulation of ROS/mTOR/4EBP1, p70S6K1/2 pathway. Aging (Albany NY) 2020;12:5693-5715

23. Atashi F, Modarressi A, Pepper MS. The role of reactive oxygen species in mesenchymal stem cell adipogenic and osteogenic differentiation: a review. Stem Cells Dev 2015; 24:1150-1163

24. Liu PC, Liu K, Liu JF, Xia K, Chen LY, Wu X. Transfection of the IHH gene into rabbit BMSCs in a simulated microgravity environment promotes chondrogenic differentiation and inhibits cartilage aging. Oncotarget 2016;7: 62873-62885

25. Al-Azab M, Wei J, Ouyang X, Elkhider A, Walana W, Sun X, Tang Y, Wang B, Li X. TL1A mediates fibroblast-like synoviocytes migration and Indian Hedgehog signaling pathway via TNFR2 in patients with rheumatoid arthritis. Eur Cytokine Netw 2018;29:27-35

26. Al-Azab M, Qaed E, Ouyang X, Elkhider A, Walana W, Li $\mathrm{H}$, Li W, Tang Y, Adlat S, Wei J, Wang B, Li X. TL1A/TNFR2-mediated mitochondrial dysfunction of fibroblast-like synoviocytes increases inflammatory response in patients with rheumatoid arthritis via reactive oxygen species generation. FEBS J 2020;287:3088-3104

27. Redondo-Castro E, Cunningham C, Miller J, Martuscelli L, Aoulad-Ali S, Rothwell NJ, Kielty CM, Allan SM, Pinteaux E. Interleukin-1 primes human mesenchymal stem cells towards an anti-inflammatory and pro-trophic phenotype in vitro. Stem Cell Res Ther 2017;8:79

28. Philipp D, Suhr L, Wahlers T, Choi YH, Paunel-Görgülü A. Preconditioning of bone marrow-derived mesenchymal stem cells highly strengthens their potential to promote IL-6-dependent M2b polarization. Stem Cell Res Ther 2018;9:286

29. Ling L, Feng X, Wei T, Wang Y, Wang Y, Wang Z, Tang D, Luo Y, Xiong Z. Human amnion-derived mesenchymal stem cell (hAD-MSC) transplantation improves ovarian function in rats with premature ovarian insufficiency (POI) at least partly through a paracrine mechanism. Stem Cell Res Ther 2019;10:46

30. Ma H, Zhang S, Xu Y, Zhang R, Zhang X. Analysis of differentially expressed microRNA of TNF- $\alpha$-stimulated mesenchymal stem cells and exosomes from their culture supernatant. Arch Med Sci 2017;14:1102-1111

31. Lin T, Pajarinen J, Nabeshima A, Lu L, Nathan K, Jämsen
E, Yao Z, Goodman SB. Preconditioning of murine mesenchymal stem cells synergistically enhanced immunomodulation and osteogenesis. Stem Cell Res Ther 2017;8:277

32. Shen L, Zhang S, Zhang X, Zhang Y, Xie L, Jiang Y, Ma Y, Li G. [Enhancing the ability of autophagy and proliferation of bone marrow mesenchymal stem cells by interleukin-8 through Akt-STAT3 pathway in hypoxic environment]. Sheng Wu Gong Cheng Xue Bao 2016;32:1422-1432. Chinese

33. Yang A, Lu Y, Xing J, Li Z, Yin X, Dou C, Dong S, Luo F, Xie Z, Hou T, Xu J. IL-8 Enhances Therapeutic Effects of BMSCs on Bone Regeneration via CXCR2-Mediated PI3k/Akt Signaling Pathway. Cell Physiol Biochem 2018; 48:361-370

34. Barhanpurkar-Naik A, Mhaske ST, Pote ST, Singh K, Wani MR. Interleukin-3 enhances the migration of human mesenchymal stem cells by regulating expression of CXCR4. Stem Cell Res Ther 2017;8:168

35. Kapranov NM, Davydova YO, Galtseva IV, Petinati NA, Drize NI, Kuzmina LA, Parovichnikova EN, Savchenko VG. Effect of priming of multipotent mesenchymal stromal cells with interferon $\gamma$ on their immunomodulating properties. Biochemistry (Mosc) 2017;82:1158-1168

36. Liang C, Jiang E, Yao J, Wang $M$, Chen $S$, Zhou Z, Zhai W, Ma Q, Feng S, Han M. Interferon- $\gamma$ mediates the immunosuppression of bone marrow mesenchymal stem cells on T-lymphocytes in vitro. Hematology 2018;23:44-49

37. Ho L, Alman B. Protecting the hedgerow: 553 and hedgehog pathway interactions. Cell Cycle 2010;9:506-511

38. Steinert AF, Weissenberger $M$, Kunz $M$, Gilbert F, Ghivizzani SC, Göbel S, Jakob F, Nöth U, Rudert M. Indian hedgehog gene transfer is a chondrogenic inducer of human mesenchymal stem cells. Arthritis Res Ther 2012; 14:R168

39. Lin T, Kohno Y, Huang JF, Romero-Lopez M, Pajarinen J, Maruyama M, Nathan K, Yao Z, Goodman SB. NF $\kappa$ B sensing IL-4 secreting mesenchymal stem cells mitigate the proinflammatory response of macrophages exposed to polyethylene wear particles. J Biomed Mater Res A 2018;106: 2744-2752

40. Tan CQ, Gao X, Guo L, Huang H. Exogenous IL-4-expressing bone marrow mesenchymal stem cells for the treatment of autoimmune sensorineural hearing loss in a guinea pig model. Biomed Res Int. 2014;2014:856019

41. Habib R, Haneef $K$, Naeem N, Khan I, Jamall S, Atta-Ur-Rahman, Salim A. Hypoxic stress and IL-7 gene overexpression enhance the fusion potential of rat bone marrow mesenchymal stem cells with bovine renal epithelial cells. Mol Cell Biochem 2015;403:125-137

42. Ma T, Wang X, Jiao Y, Wang H, Qi Y, Gong H, Zhang L, Jiang D. Interleukin 17 (IL-17)-induced mesenchymal stem cells prolong the survival of allogeneic skin grafts. Ann Transplant 2018;23:615-621

43. Sivanathan KN, Coates PT. IL-17A-induced mesenchymal stem cells have promising therapeutic value for clinical translation. Kidney Int 2018;93:771-773 
44. Bie Q, Zhang B, Sun C, Ji X, Barnie PA, Qi C, Peng J, Zhang D, Zheng D, Su Z, Wang S, Xu H. IL-17B activated mesenchymal stem cells enhance proliferation and migration of gastric cancer cells. Oncotarget 2017;8:18914-18923

45. El-Zayadi AA, Jones EA, Churchman SM, Baboolal TG, Cuthbert RJ, El-Jawhari JJ, Badawy AM, Alase AA, El-Sherbiny YM, McGonagle D. Interleukin-22 drives the proliferation, migration and osteogenic differentiation of mesenchymal stem cells: a novel cytokine that could contribute to new bone formation in spondyloarthropathies. Rheumatology (Oxford) 2017;56:488-493

46. Rostami M, Haidari K, Shahbazi M. The human IL-23 decoy receptor inhibits T-cells producing IL-17 by genetically engineered mesenchymal stem cells. Int J Cell Biol 2018; 2018:8213912

47. Sriramulu S, Banerjee A, Di Liddo R, Jothimani G, Gopinath M, Murugesan R, Marotta F, Pathak S. Concise review on clinical applications of conditioned medium de- rived from human umbilical cord-mesenchymal stem cells (UC-MSCs). Int J Hematol Oncol Stem Cell Res 2018;12: 230-234

48. Mateos J, De la Fuente A, Lesende-Rodriguez I, Fernández-Pernas P, Arufe MC, Blanco FJ. Lamin A deregulation in human mesenchymal stem cells promotes an impairment in their chondrogenic potential and imbalance in their response to oxidative stress. Stem Cell Res 2013;11: $1137-1148$

49. Simic P, Zainabadi K, Bell E, Sykes DB, Saez B, Lotinun S, Baron R, Scadden D, Schipani E, Guarente L. SIRT1 regulates differentiation of mesenchymal stem cells by deacetylating $\beta$-catenin. EMBO Mol Med 2013;5:430-440

50. Xiao L, Sobue T, Esliger A, Kronenberg MS, Coffin JD, Doetschman T, Hurley MM. Disruption of the Fgf2 gene activates the adipogenic and suppresses the osteogenic program in mesenchymal marrow stromal stem cells. Bone 2010;47:360-370 